Original Article

Received/Accepted Dates

25.09.2021/10.29.2021

$\mathrm{DOI}$

10.52096/usbd.5.23.5.12
International Journal of Social Sciences

Uluslararası Sosyal Bilimler Dergisi

www.sobider.net ISSN: 2548-0685

\section{Organik Tekstil Ürünlerinin Pazar Yapısı}

Ali TAŞTEKIN

alitastekinn@gmail.com

https://orcid.org/0000-0002-1824-3508

\title{
Özet
}

Günümüzde çevremize organik olan tekstil ürünlerinin insan sağlığına sağlamış olduğu katkının yanı sıra çevremize de oldukça katkı sağlamaktadır. Organik tekstilin en önemli unsurlarından biri olan ana maddesi ise pamuk üretiminde kullanılan ilaçların kimyasal olmaması ayrıca çevremizde yaşayan canlılarında daha temiz bir ortamda yaşam olanağı sağlamasıdır. Organik tekstilin insanların hayatında oldukça önemli yer alması ve günden güne insanların organik tekstil hususunda bilinçlenmesi ise oldukça önemli bir olgudur. İnsanların bilinçlenmesi üzerine organın giyime ise günümüzde tercih edilmesi daha çok önem taşımaktadır. Araştırmaya bağlı olarak ulaşılan verilerin analizinde, SPSS (Statistical PackageforSocialSciences) WindowsFor 22.0 programı kullanılmıştır. Veriler değerlendirileceği zaman tanımlayıcı istatistik yöntemlerinden yararlanılmıştır. Ölçek sorularının cevaplarının puan değerlerinin kullanılması sonucu tutuma yönelik değer puanı belirlenmiştir. Cinsiyeti, yaşı, medenî durumu ve eğitimle ilgili değişkenlerine bağlı memnuniyetlerin karşılaştırılmaları yapılmıştır.

Anahtar Kelimeler: Tekstil, Pazar, Tarım, Organik

\section{Organic Textile Products Market Structure}

\begin{abstract}
In addition to the contribution of organic textiles to human health to our environment today, it also contributes significantly to our environment. The main ingredient of organic textiles, which is one of the most important elements, is that the drugs used in cotton production are not chemical, but also provide the opportunity to live in a cleaner environment in their creatures living around us. Organic textiles are very important in people's lives and day by day people become aware of organic textiles is a very important phenomenon. On the awareness of people, it is more important
\end{abstract}




\section{Organik Tekstil Ürünlerinin Pazar Yapısı}

that the organ is preferred to clothing today. SPSS (Statistical Package for Socia 1Sciences) for Windows 22.0 program was used in the analysis of the data obtained in the study. Descriptive statistical methods were used to evaluate the data. Attitude level score was determined as a result of using score values for answers to scale questions. Satisfaction comparisons were made according to gender, age, marital status and education variables.

Key Words: Textile, Sunday, Agriculture, Organic

\section{Giriş}

İnsanlar asırlar boyu çevrelerini gelecekten kaygı duymaksızın işlemiş, doğal zenginlikleri ve onun sunduklarını kullanmıştır. İnsanların çevreyle ilişkileri, çevreden faydalanmaktan çok öte geçmiş onu sağladıklarından sınırsız şekilde yararlanmaya dönmüştür. Yani ilkel insanla çevresi arasında sağlanan uyumu bozan, insanın kendisini doğadan güçlü görmesi olmuştur. Bundan dolayı günümüzde çevresel sorunlar dünyada gündemi oluşturan önemli konular arasında yer almıştır. Çevrenin sorunlarını çözmede etkin çevre politikaları oluşturmak ve çevresel denge sağlamak insanlar için önemli hale gelmiştir.

Türkiye'nin hazır giyim ve tekstil sanayinde gösterdiği gelişmenin asıl temelindeki neden önemli derecede pamuk üretebiliyor oluşu yatmaktadır. Bunun nedeni, tekstil sanayinde üretimin ilk zamanlar yalnızca pamukla ilgili olarak başlıyor oluşu, sonrasından suninin yanında sentetikli lif üretiminin gelişmiş olmasıdır. Pamuk özellikle tekstille ilgili sektörün ana girdi malları ile yüksek oranda katma değer kazandıran üretim hammaddesi bölümü için üretilir. Doğal bir madde olarak pamuğun oluşu, kesik olan belirli boyda lif yapısının özel bir duruma sahip oluşu, içindeki madde ile minerallerin çok fazla çeşitli olması, havayı suyu ve yine ısıyı tutma yönüyle mükemmel bir duruma sahip olması, insanın yapı ile sağlığına elverişti bulunması, giyim yanında dekoratif, spor, tıp gibi alanlarda kullanılıyor olması pamuk lifine verilen önem ve değeri anlatma konusunda yeterlidir. 2000'li yıllarla birlikte tekstil organik kavram olarak dünyada her kesim tarafından talep edilen bir durum haline gelmiştir ${ }^{1}$. Dolayısıyla günümüzde insanların büyük bir bölümü organik kumaşları kullanmanın bilincine varmışlardır.

\footnotetext{
${ }^{1}$ Akgüngör, Miran, Akbay, 2010: 299-313
} 
Türkiye'de üretilen organik tekstil başlangıçta hammadde olarak değerlendirilirken, günümüzde işlenerek katma değeri yüksek ürünlerin sayısı giderek artmaktadır². Dünya da ilk defa organik pamuğun Türkiye'de üretilmeye başlanılmış olması durumu ilk zamanlarda yabancı işletmelerin yaptıkları talepler istikametinde meydana gelerek, takip eden yıllarla birlikte Türkiye'yi bu sektörde sözü geçen ülkeler konumuna ulaştırmıştır. Organik tekstil sektörünün beklenen öneme kavuşması pamuktaki organik üretime paralel olarak gerçekleşmiştir. Tekstile ait alt sektör olarak özellikle organik pamuk piyasası en hızlı gelişme gösterenlerdendir. Organik olarak üretile bebek mamasından bebek kozmetik ürünlerine kadar birçok alandaki oluşan talep 0-12 ay arasındaki bebek anne-babalarının hassasiyetine bağlı olarak yurt içinde yurt dış gibi artış göstermiştir.

Türkiye'de organik olan tekstil ile hazır giyim ürünlerinin her çeşidi üretilmektedir ${ }^{3}$. Ülkemizde üretilen organik tekstil ürünleri de Avrupa pazarında önemli bir yere sahiptir. Ülkemizden ''Fuar Baby" markasıyla dünyaya açılan “Akın Tekstil”" üretmiş olduğu bebek kıyafetleriyle Almanya'nın ünlü '’Babywalz”' mağazasına girmeyi başarmıştır'.

\section{Organik Tekstil Tanımı Amacı ve Önemi}

Organik tekstil ürünleri insan sağlına büyük bir katkı sağlamasının yanı sıra çevremize de önemli bir ölçüde fayda sağlamaktadır. Tekstilin ana maddesi olan organik pamuk üretiminde kimyasal ilaçların kullanılmaması insanlara ve eko sistemde yaşayan bütün canlılara daha temiz bir dünya sunmaktadır. Organik tekstilin insan hayatında önemli bir yer etmesi ve bilinçlenen insanların bu durumu daha da çok önemsemesi giysi tasarımlarında organik kumaşların kullanımının artmasına neden olmaktadır. Giysilerde organik kumaşların yaygın olarak kullanımı insan sağlığına ve doğal çevreye sağladığı katkı nedeniyle önem taşımaktadır. Bu durum çalışmanın gerekliliğini ve çıkış noktasını ortaya koymaktadır.

Çevre bilincinin gelişmesi, ozon tabakasında ki sorun ile dünyanın tehlikeye girebilecek oluşu şeklindeki konuların gündeme gelmesiyle başlayan Organik tarımın geçmişi 20. Yüzyıla kadar dayanmaktadır ( Kuyumcu, 2011: 11). Organik tarım ürün kalitesiyle birlikte ürün miktarını da

\footnotetext{
${ }^{2}$ Demiryürek, Aydoğan, 2010: 333-340

${ }^{3}$ Kuyumcu, 2018:1

${ }^{4}$ Kuyumcu, 2018:1
} 


\section{Organik Tekstil Ürünlerinin Pazar Yapısı}

arttırması düşünülmektedir. Dünyadaki eko sistemin kontrollü biçimde dengede tutulması hem eski ile yeni teknolojik yöntemlerin birlikte kullanılması hem de bilimsek araştırmalarla sağlanabilmektedir. Organik tarım üretimle ilgili teknikleri daha kalıcı ve iyi bilinmesiyle sağlanabilecek bir sistem olduğu söylenmektedir ( Arslan, Ersun, 2011:28). 17. Yy.la birlikte insanın doğaya hâkim olma durumu giderek artış göstermesiyle 1800’ler sonrasında il önce Avrupa ve sonrasında da tüm dünyada oluşacak sorunların sebebi olmaya başlamıştır (Görmez, 2007:9). Sanayi devrimi süreci ile çevre dengesinin tahrip oluşu ve bozulmaya başlamasıyla oluşacak tehlikeli durum insana tarafindan gerçekleştirilmiştir. (Görmez, 1989:6). Günümüzle birlikte insanlar daha bilinçlenmişler ve sonrasında çevreye karşı ilgileri artarak dikkatleri ve bilinçleri değişmiştir. (Keleş ve Hamamcı 1997:18). Çevrenin temiz ve kirlenmemiş olması kuşkusuz insanlar için hayati önem taşımaktadır.

Bu nedenle eko sistemde var olan dengeyi korumak için organik tarımın önemi yadsınamaz bir gerçektir. Organik tarımın beraberinde getirdiği, organik tekstil alanı da insanlara ve dünya da yaşayan bütün canlılara daha temiz bir çevre ve kimyasal maddelerden uzak bir yaşam alanı sunmaktadır. Giysilerde organik kumaşların kullanım durumunun yaygınlaşması insan sağlığına ve doğal çevreye büyük ölçüde katkı sağlaması nedeniyle konu önem taşımaktadır.

Talep edilen organik pamuklu ürünlerin \%15,6'l1k bir miktarını ülkemiz tek başına gerçekleştirirken, organik giysi tasarımı, üretimi ve pazarının bu üretimi destekler özellikte olması gerekmektedir. Ülkemizin bu avantajı kullanarak pazardan büyük bir pay alabilme potansiyeli konunun diğer bir önemini oluşturmaktadır ${ }^{5}$ (Çelik, A. \& Başal, M. (2021). Giysi tasarımında organik kumaşların kullanım durumuna yönelik detaylı bir çalışmanın bulunmaması ve bu konuya dikkat çekilerek farkındalık oluşturulması araştırmayı önemli kılmaktadır.

\footnotetext{
${ }^{5}$ Çelik, A. \& Başal, M. (2021). Farklı Kültürlere Ait Yöneticiler ile Türk Yöneticiler Arasındaki Çatışma Nedenleri ve Müzakere Tarzlarının Karşılaştııılması: İstanbul'daki Tekstil Firmalarında Çalışan Üst ve Orta Kademedeki Yöneticiler, IJSS, 2021, Volume 5, Issue 22, p. 1-32.
} 


\section{Dünya’ da Organik Pamuk ve Tekstil Ürünlerinin Gelişimi}

Dünya Ticaret Örgütü'nün 1995 yılıyla birlikte imzalamış olduğu ve yine 2005 yılı sonrasında tekstille birlikte hazır giyim ticaretinde tamamıla liberalleşme önerisinde bulunan Tekstil ile Hazır Giyim Anlaşması'nın ardından 2001'de Çin Halk Cumhuriyeti'nin Dünya Ticaret Örgütü'ne üye olup söz konusu anlaşmayla ilgili taraf olabilmesi Dünya'nın hazır giyim, tekstil yanında deri ürünleri ile dericilik sektörlerinde farklı bir süreç başlamasına neden olmuştur. Bu yolla 2000'li yıllarda "üretim merkezi" haline gelen Çin, bu dönemde ithalatçı ile yatırımcı kimliğine sahip olmaya başlamış, Bangladeş ile Vietnam benzeri ülkeler, düşük üretim giderlerinin etkisi ve bunun yanı sıra önemli diyebileceğimiz ithalat yapan ülkelerle imzaladıkları tercihe bağlı ticaret anlaşmaları ile düzenlemeler aracılığıyla önemli üretici ve ihracatçı olmuştur. ${ }^{6} 2008$ 'de Amerika'da başlayan finansal kriz 2011 yılı sonrası Avrupa Birliği ülkelerini de etkilemiş ve Dünya'da tüketici talebi azalmış ve bu sektörlerde ticaret yön değiştirmiştir. 2009 - 2010 yılları bu sektörlere bağlı küresel ticaretin \%15'lik değerlere ulaşan oranda iniş yaşadığı dönem olmuştur. Fakat 2010 yılı sonrası dönemde bir toparlanma yaşanmış, 2011'de Dünya tekstil ihracatının toplam ticaretle paralel olarak \%17 arttığı ve 294 milyar dolara ulaştığı, hazır giyim ihracatınınsa \%17 oranda artışa bağlı 412 milyar dolara, deri ile deriye bağlı ürünlerin ihracatının \% 18 artışla 162 milyar dolara çıktığı gözlenmiştir. 2011'de üç sektör dünya ticaretinde \% 4,7 paya sahip olmuştur. $^{7}$

Çin'in tekstil yanında hazır giyimde de en önemli üretici ve ihracatçı ülke olmasını 2011 yılında da sürdürdüğü görülür. Söz konusu sektörlerde Dünya’da ikinci büyük tedarikçi Avrupa Birliği ülkeleri Çin'e, Türkiye’ye, Bangladeş’e, Hindistan'a ve benzer ülkelere üretim yaptırmasıyla birlikte en önemli alıcı konumuna gelmiştir. Avrupa Birliği ülkelerinden sonra üçüncü sıradaki Hindistan, 2011 yılı verileri göstermektedir ki tekstil ile hazır giyim ürünlerinde görülen ihracat değeri \%23 oranda artırmıştır. ${ }^{8}$

Türkiye ise ITC (InternationalTrade Center) - Uluslararası Ticaret Merkezi'nden elde edilen verilere bağlı olarak, 2011'de Dünya tekstil sektörünün ihracatında \% 3,7'lik oranla 8'inci sırada,

\footnotetext{
${ }^{6}$ Willer, Klicher, 2011: 299

${ }^{7}$ Çalışkan, Çalışkan, Karanlık, Arslan, 2009: 461-466

${ }^{8}$ Çalışkan, 461-466
} 
hazır giyime yönelik ihracatın ise \% 3,4'lük oranla 7'nci sırada yer almıştır. Çin, \%25 oranla en büyük deri ve deri ürünleri ihracatçısıdır. Çin'le ilgili olarak, 2011'de \% 20 oranında artışla birlikte 41 milyar dolar değerinde ihracat yapmıştır. Çin’i İtalya, Hong Kong ve Fransa izlemiştir (ITC International Trade Center-Uluslararası Ticaret Merkezi.). ${ }^{9}$

Dünya'da hazır giyim ihracatı \%80 oranla Avrupa Birliği ülkeleri ve Amerika'ya gerçekleşmiştir. Tekstilde de büyük alıcılar aynı zamanda üretici ve tedarikçi konumunda yer alan Avrupa Birliği, Çin, Amerika, Vietnam'la birlikte Türkiye'nin oluşudur. ${ }^{10}$ Deriye bağlı olarak üretim yapan sektörlerdeyse ihracatçılar olarak en büyük değeri \%39'luk oranla $A B(27)$ ve \%22 oranındaki bir payla ABD’ye aittir. Ülkeler kategorisinde bakıldığında diğer ihracat gerçekleştirenler sıralandığında Hong Kong, İtalya ile Çin devletlerinin olduğunu görmekteyiz. Oransal olarak tekstil ile hazır giyinme dayalı ürün gamında Asya ilkeleri en büyük miktara sahiptir. Ucuz iş gücünün elinde olması bunun en önemli sebebi olarak söylenebilmektedir. ${ }^{11}$

\section{Türkiye’ye Ait Organik Pamuk ile Tekstil Ürünlerinin Gelişime Süreci}

Gelişimini İngiltere'de 19. yüzyılda, Japonya'da 20. yüzyılda, Tayvan ve Kore'deyse 50'li yıllarda gerçekleştiren tekstil sektörünün; tarihi Türkiye'de köklüdür. Anadolu'da dokumacılık Selçuklular eski dönemlere dayanır. Osmanlı İmparatorluğu zamanında Selçuklu döneminden gelen deneyim doğrultusunda sanayinin tekstil merkezli geliştiği görülür. Söz konusu dönemde; dokumada Denizli ile Tokat, ipek ağırlıklı ürünlerdeyse Bursa iline ait bölgede küçük miktarda atölyeler şeklinde üretim yapıldığı görülür. 1915'te sanayi sektöründeki işletmelerin birçoğu dokuma tesislerinden oluşmuştur. Aynı dönemde 22 adet kamu sanayi işletmesinden 18 tanesi, 28 adet anonim şirketten 10 tanesi, 214 adet özel sektör işyerinden 45 tanesi ve yani toplamda 264 adet sanayi işletmesinden 73 tanesi tekstil faaliyetleri yürütmektedir. ${ }^{12}$

1933 yılında Devlet'in Sümerbank'1 kurması, sektör açısından önemli bir adımı oluşturmuştur. Sümerbank'ta yetişenler, edindikleri bilgi ve deneyimle ilerleyen süreçte özel sektörü oluşturmuş ve gelişimine katkı sağlamışlardır. Sanayi yatırımlarının ve ilk kalkınma planlarının öncelik

\footnotetext{
${ }^{9}$ Willer, Klicher, 2011: 299

${ }^{10}$ Willer, Klicher, 2011: 299

${ }^{11}$ Willer, Klicher, 2011: 299

${ }^{12}$ Demiryürek, Aydoğan, 2010: 333-340
} 
tanıdıklar tekstil sektörü, Türkiye'de pamuk üretiminde söz sahibi olunması nedeniyle de kalkınmanın pamuk ve tekstil temelli olarak gerçekleşmesine zemin hazırlamıştır. ${ }^{13}$

1960’l1 yıllarda sanayileşme hareketi başlatılmasından sonra 70'li yıllarda küresel yönlü gerçekleştirilen tekstille birlikte hazır giyim alanındaki sanayisel alanda yol almış ülkelerden sıyrılarak gelişmekte olanların hâkimiyetine geçmiştir. Ele alınan bu yıldaki sektörel bazlı teknoloji kullanımının artmasıyla, bilgi birikim olarak artması yanında teknik alanda da gelişmiştir. 80'li yıllarda ihracata endeksli büyüme stratejileri oluşturulması sonucunda ihracatta artış sağlanmıştır. 1990'lı yıllara dek sektör çeşitli şehirlerde yayılmış ve bu şekilde gelişme göstermiştir. 1990 yılında \% 12,2'lik artış miktarına bağlı olarak en süratli gelişen sektör olma başarısına erişmiştir. Bu yolla Türkiye 1970'li yıllarda sadece ham pamuk ihracatçısı iken 1990'lara gelindiğinde Avrupa piyasasına ait en fazla hazır giyim ile tekstil ihracatını yapan ülke konumunu ele geçirmiştir. ${ }^{14}$

Dünya Ticaret Örgütü’nün 1995 yllında kabul edilmesiyle gerçekleşebilmiştir. Bu süreç sonucunda ulusal olmayan pazarda rekabeti artıran yeni bir döneme girilmiştir. Anılan dönemin Türk tekstil ve hazır giyim sektörlerine önemli ve olumlu etkileri vardır. Anılan döneme dek düşük maliyetli ürün üreterek rekabet etmeye gayret gösteren Türklere ait tekstille birlikte hazır giyimin sektörek durumu, klasik olmasının yanında basit olarak ele alın ürünlerin rekabetini sürdürmek yerine, yüksek oranda katma değer sağlayan tekstil ürünleri üretmesinin yanında hazır giyim alanında markalaşarak ilerlemeyi tercih etmişlerdir. ${ }^{15}$

2000'e ait y1llarda meydana gelen ekonomik yönlü kriz bu sektörü daha olumsuz biçimde etkilemiş ve ihracat rakamları azalma göstermişse de; 2005 yılında Dünya'da en fazla miktarda 4. Olan hazır giyim ile 11. Sıradaki tekstile bağlı tedarikçi olma konumuna erişilmiştir. Dünya tekstil ile hazır giyim ihracatında elinde tutmasının yanında Türkiye'nin ekonomisinin toplam ihracatında edindiği pay nedeniyle sektör bugün ülkede temel sanayilerinden biri olmuştur. Tekstil üretiminin yanında hazır giyim ile deri ürünleri sektörü açısından, ulusal gelirdeki payı, sağlanan istihdam ve ihracata ilişkin yüksek potansiyelle ülke ekonomisinde lokomotif sektörler arasındadır. Günümüzde fazla oranda dış ticarete bağlı fazlalık veren sektörler, oluşturdukları istihdamla işsizliği azaltmaya ve toplum refahının artmasına çok ciddi katkı sağlarlar. ${ }^{16}$

\footnotetext{
${ }^{13}$ Ersun, Kahraman, 2011: 101

${ }^{14}$ Demiryürek, Aydoğan, 2010: 333-340

${ }^{15}$ Ersun, Kahraman, 2011: 101

${ }^{16}$ Ersun, Kahraman, 2011: 101
} 


\section{Organik Tekstil Ürünlerinin Pazar Yapısı}

Söz konusu ele alınan bu üç alan ülkede gayrisafi yurtiçi hâsılasının \% 10luk miktarından fazlasıyla birlikte imalata dayalı sanayide oluşturulan katma değerin \% 16'lık alanını sağlar. Sektörlerde ürün kalitesi, modayı ve trendleri belirleme gücü üst düzeyde olan tasarımlar ve yüksek teknolojisi sebebiyle Dünya'da önemli yer sahibidir. İplik üretiminde Kahramanmaraş, İstanbul, Adıyaman, Gaziantep, Bursa ön plana çıkarken, havlu, bornoz, ev tekstili imalatında Denizli, iplik ürününün yanında, battaniye ve geri dönüşümde Uşak, terbiyede Çorlu ile Çerkezköy, pamuklu dokuma ve terbiyede Adana, polipropilende (termoplastik bir polimer), dokusuz yüzeyde, makine halıcılığında Gaziantep, hazır giyim ve örme üretiminde İstanbul ön plana çıkan diğer illerdir. İstanbul- Tuzla, İzmir -Menemen, Tekirdağ -Çorlu, Uşak, Bursa, Balıkesir -Gönen, Bolu -Gerede, Isparta, Hatay, Manisa -Kula deri işlemenin yoğunlaştığ1 bölgelerdir. Ayakkabı yan sanayi işletmelerinde dağılım \% 50 miktarıyla İstanbul iken diğer işletmeler İzmir'de, Konya'da, Gaziantep’te, Bursa' da yer almışlardır. Deri hazır giyim işletmeleri çoğunlukla İstanbul ile İzmir'de yer almışlardır.

2008 - 2009 yıllarına ait gerçekleşen krizde kapasiteye yönelik kullanma oranları düşüş eğilimi göstermiş, kriz sonrası süreçteki kapasiteyle ilgili kullanım oranları genel görünümlü olan toparlanma eğilimine dönmüştür. Tekstil ile hazır giyim alanındaki krizden önceki performanslarını yakalayamamış, deriyle birlikte deri katkılı ürünlere bağlı sektörel kapasite kullanım değerinde oluşan kriz öncesi performansın bir değer oranında üzerine çıkmıştır. Bununla birlikte tekstil ve hazır giyim sektörlerinde 2011 yılından sonra çoğunluğu yenileme nitelikli yatırımların yapılması söz konusudur. 2012 yılı Sosyal Güvenlik Kurumu kayıtları, 11.996.880 sigortalı çalışandan 3.171.015'inin imalat sanayinde kayıtlı olduğunu, bunların 428.778'inin tekstil üretiminde, 451.165lik miktarı hazır giyim üretiminde, 60.242'sinin ise deriden yapılan ürünlerin imalatına yönelik istihdamın yapıldığg bilinmektedir. Bu durumun tersine tekstil ise hazır giyim sektörleri bağlamında kayıt dışı çalışan sayısı da hayli yüksektir. Söz konusu kayıt dışılık incelendiğinde, 450.000'e yakın çalışanın tekstilde, 1.500.000'e yakın çalışanın da hazır giyimde, 2.000.000 civarı kişinin istihdam edildiği görülmektedir. ${ }^{17}$

Sektörlerdeki emeğe bağlı yapısal sistem ve küresel yönlü işçilikte görülen maliyetlerde meydana gelen fazla rekabet oluşabilecek kayıt dışı istihdamında ilerlemesine firsat vermektedir. Bu kayıt dışı durum önemle ele alınırsa tekstil, hazır giyim ve deri ürünleri sektörlerinin tüm sektörler içerisindeki istihdam oranı \% 12 civarındadır. Tekstile bağlı alandaki en önemli oranda istihdamı

\footnotetext{
${ }^{17}$ BSTB,2013, 16 (Bilim, Sanayi ve Teknoloji Bakanlığı).
} 
50-249 çalışan personeli olan orta ölçekli işletmeleri meydana getirirken, hazır giyim ile deri ürünleri alanındaki personel sağlamdaki 50'den az çalışana sahip küçük ölçekli işyerleri sağlar. ${ }^{18}$ Türkiye İstatistik Kurumu'nun verilerine göre söz konusu üç alandaki istihdam artışının sürdüğü, tekstil ile hazır giyim sektörlerinde istihdamın eski performansını yakalayamadığı gözlenmiştir. Dünyada genel olarak Ar-Ge alanında yapılan harcamaların ortalama 3 kat artış göstermesi 1995 ile 2010 arasındaki süreçte meydana gelmiştir. Ar-Ge konusuna önem veren ülkelerin en önde gelenleri Amerika, Kanada, Çin ile Japonya olduğu söylenebilir. Millî gelirlerinden \% 2-3'ünü ArGe'ye yatıran ülkeler Ar-Ge'ye neredeyse Türkiye'nin GSMH'sı kadar bir tutar ayırmaktadır.

Türkiye açısından ise G.S.Y.H. kapsamında Ar-Ge için yapılan harcama 2011 yılı verilerine göre bir önceki yıldan \%20,4 artmış ve 11.154 milyon € olarak gerçekleşmiştir ${ }^{19} .2011$ yılında GSMH içinde Yurtiçi Ar-Ge harcamaları \% 1,11 paya sahip olabilmiştir. Bu anlamda ülkemiz için 2023 hedefleri ile Avrupa'nın 2020 yılı stratejik hedefi olarak \%3lük bir orana sahip olduğu belirlenmiştir. $^{20}$

Türkiye İstatistik Kurumu tarafından son yayımlanan 2011 y1lına ait veriler doğrultusunda imalat sanayi olarak bilinen sektörlerden tekstil için \%3,12 Hazır giyim için \%0,52 ve yine deri ürünler konusunda da \%0,052 oranlarında Ar- Ge için harcama yapılmıştır. Bu bağlamda genel istihdam oranları ile Ar-Ge personeli istihdam oranlarına dair karşılaştırma Tablo 1'de sunulmuştur.

Tablo 1: Genel Olarak İstihdam ile AR-GE Bölümü Personelin İstihdam Edilme Oranlarının Karşılaştırması

\footnotetext{
${ }^{18}$ BSTB,2013,16 (Bilim, Sanayi ve Teknoloji Bakanlığı).

${ }^{19}$ TÜİK - Türkiye İstatistik Kurumu

${ }^{20}$ BSTB,2013: 16 (Bilim, Sanayi ve Teknoloji Bakanlığı).
} 


\begin{tabular}{|lcc|}
\hline & İstihdam \% & AR-GE Personeli İstihdamı \% \\
\hline Tüm sektörler içinde imalat sanayi & 28,6 & 47,9 \\
\hline İmalat Sanayi & & \\
\hline Tekstil Sanayi (T) & 100 & 100 \\
\hline Hazır Giyim Sanayi (H) & 12,3 & 2,65 \\
\hline Deri ve Deri Ürünleri (D) & 13,5 & 0,68 \\
\hline Toplam THD & 1,6 & 0,14 \\
\hline
\end{tabular}

İmalatının yapıldığı sektör olarak tekstilde $\% 2,65$, hazır giyim $\% 0,68$ ve deri ürünü konusunda \% 0,14 oranlarında Ar-Ge personeli bulundurmaktadır. Bu da sektörler açısından Ar-Ge çaltıma oranının düşük seviyelerde olduğunu göstermektedir. ${ }^{21}$

\section{Tekstildeki Organikliğin Pazardaki Yapısı}

90’lı yıllarda organik tekstilin ürünlerinin ortaya çıkışıyla bu ürünler sadece bazı mağazalarda yer almaktaydı. Hem tüketici hem de üretici açısından çevresel konularda bilinçlenince organik tekstil ürünlerinin kullanımında artış yaşanmıştır. Kullanımın yaygınlaşmasıyla organik tekstil ürünleri kaliteli hale gelmiş ve her çeşit renk kullanılmak suretiyle ve modaya uygun ürünlerin satışına hız verilmiştir. 2000 yılında harmanlama yöntemi geliştirilmiştir. Söz konusu yöntemde organik pamuğun kullanılıyor olması \% 3-5 gibi oranlardadır. $\mathrm{Bu}$ sistemle pahalı olarak bildiğimiz organik pamuğun üretim sürecindeki maliyeti etkilemesi sınırlandırılmış oldu. İleriki dönemlerde satışlar arttıkça ürünlerin organik pamuk oranları da kademeli olarak arttırılmıştı. Büyük ve orta ölçekli çok sayıda işletme 2006 yılı sonuyla harmanlama şekliyle yapılan üretimi örnek alarak organik pamuktaki dönüşümü program dahilinde kullanmaya başlamıştır. Organik pamuğun talebinin artması sonucu birim maliyetlerde de ciddi azalmalar olmuştur ${ }^{22}$. Sektörel altyapı sorunu zamanla giderilmiş ve işletmelerin organik tekstil üretim kapasite ve becerileri artmıştır. Bu gün $\% 3$ ile 5 oranında organikliğe sahip olan ürünler tüketiciler tarafından rakiplerine göre daha fazla

\footnotetext{
${ }^{21}$ BSTB,2013.16 (Bilim, Sanayi ve Teknoloji Bakanlığı).

22 (Çelik, A. \& Başal, M. ,2021
} 
ücreti de olsa talep edilmektedir. Bundan dolayı işletmeler ciddi kar avantajına sahip olan bu ürünleri satmayı tercih etmektedirler. ${ }^{23} \mathrm{Bu}$ da ürünlere olan talebin her geçen gün artmasına neden olmaktadır. Organik tekstil ürünleri uluslararası fuarlardan birçok mağaza ve internete birçok alanda alıcı bulabileceği görülmektedir. Organik tekstil ürünler konusunda Türkiye birçok imkâna sahiptir. Buradaki tarım arazileri uygundur ve bunları işleme konusunda sanayiye de sahip olan az bulunan ülkeler sınıfındadır. Bunlardan yine uygun tecrübeli, altyapısı olan üretim kapasitesi iş gücünü de barındırmasıdır. Avantajlarının en önemlisinden biri de gelişmiş olan ülkelere konum olarak daha yakın oluşudur. ${ }^{24}$ Organik tekstil ürünler konusunda en önemli ülkeler olarak, Amerika, İsviçre, Almanya, İngiltere Fransa, İsveç, Japonya, İtalya ve Hollanda'yı sayabiliriz. ${ }^{25}$ Sahip olunan bu önemli avantajlar Türkiye'ye sektör olarak büyük firsatlar sunmaktadır. İlerleyen yıllarda bu durum dünya liderliğini de getirecektir. Bu durum hem ülkedeki ekonomik duruma hem de sanayide önemini arttırmaktadır. ${ }^{26}$

\section{Organik Tekstil Pazarında Faaliyet Gösteren Başlıca Firmalar}

İzmir bölgesindeki geniş ve verimli tarımsal alanlar, uluslararası ticaret yollarının güzergâhında bulunmak Türkiye için hazır giyim ile tekstil alanında önemli yer sahibi olmasını sağlamıştır. Yerel tekstil ürünü niteliğine sahi olan tiftikle beraber İran'dan o dönemin şartlarıyla kervan yoluyla gelen ipek İzmir ticaretinde önemli bir yere sahiptir. Türkiye genelinde İzmir, organik pamuk üretiminin lideri durumundadır. Ancak ne var ki ekim alanları gün geçtikçe azaldığından pamuk üretiminde ciddî azalma söz konusudur. Dünyadaki en iyi pamuğu yetiştiren üçüncü bölge olduğu kabul edilen Turgutlu'da 2003'te 80 bin dekarlık alanda pamuğun ekildiği alan itibariyle 2010 yılında 70 bin dekara, Tire'de ise 5 yıllık süre içinde 90 bin dekarlık ekim alanı 2 bin dekarlık miktara düştüğü görülmektedir. ${ }^{27}$

İzmir Ticaret Odası ile Ege Bölgesi Sanayi Odası kayıtları neticesinde İzmir'de yaklaşık 3.500 işletme tekstil ve hazır giyim alnında çalıştığı söylenebilir. Buna göre İzmir 2011 de 210 milyon dolarlık tekstil ihraç rakamına ulaşmıştır. Böylelikle İzmir Denizli ile yarışır duruma gelmiştir.

\footnotetext{
${ }^{23}$ https://www.dunya.com/turkiyede-organik-tekstil-sektoru-ve-organik-tekstillerin-sundugu-firsatlar,-oga-85329h.htm

${ }^{24} \mathrm{https}$ ://www.dunya.com/turkiyede-organik-tekstil-sektoru-ve-organik-tekstillerin-sundugu-firsatlar,-oga-85329h.htm

${ }^{25} \mathrm{http}: / / w w w . o r g a n i k t u r k i y e . c o m . t r / 2014 / 02 /$ turkiyede-organik-tekstil-sektoru/

${ }^{26} \mathrm{https}$ //www.dunya.com/turkiyede-organik-tekstil-sektoru-ve-organik-tekstillerin-sundugu-firsatlar,-oga-85329h.htm

27İzmir Atatürk Organize Proje ve İş Geliştirme Birimi,Sanayi Bölgesi İAOSB Haber Dergisi Temmuz 2012
} 
2017 de, Ege Giyim Sanayicileri Derneği'nin çalışmaları bağlamında İZFAŞ tarafından 27-30 Nisan 2017 tarihleri arasında 7. Organik Ürünler Fuarı düzenlenmiş̧ir.

Türkiye'nin organik giyim alanında faaliyetlerini sürdüren çok sayıda işletme fuarda ürün sergilemişlerdir. Dünyanın önde gelen ülkelerine organik giysi ihracatı gerçekleştiren bu işletmelerle kendi markaları ile hem yurtdışı hem de yurtiçine ürün satan firmalar bu fuarda bir arada yer almıştır. İzmir'de organik giyimde hem kapasite hem de kalite açısından çok nitelikli işletmeler bulunur. Özellikle çocuk giyim başta olmak üzere kadın giyim, erkek giyim, hamile giyim, ev tekstili benzeri çok sayıda alanda organik tekstil üretildiği görülmektedir.

Bununla birlikte Güneydoğu Anadolu Bölgesi'nde organik pamuk başta olmak üzere organik ürün tarım faaliyetlerini sürdüren çok sayıda işletmenin olduğu görülmektedir. Güneydoğu Anadolu Bölgesi'nde organik tarım faaliyetleri yürüten ticarî işletme sayısının 57 olduğu tespit edilmiştir. ${ }^{28}$ Özellikle konvansiyonel pamuk üretiminde oldukça yüksek pay sahibidir. Güneydoğu Anadolu Bölgesi Türkiye'de yapılan organik bazlı pamuk üretimindeki \%50 den \%75 aralığına zamanla ilerlemiş̧ir. Gelecekte sulama imkanına sahip olacak alanlar artırılarak hem konvansiyonel hem de organik pamuk üretiminde de artış beklenmektedir. Bunun temel sebepleri de;

- Bölgede var olan değer zincirinin gelişmesi ve organik liflerin hazırlanarak uzağa gitmesinin gerekmemesi.

- Organik tekstile ait tüm üretim aşamalarının bölgede hızlı biçimde gelişmesi.

- Yine bölgede organik pamuk tarımı yapan 109 çiftçi, 10 çırçır üretim alanı ve 8 tanende firmanın oluşu.

- Son olarak dünyada var olan 80 adet büyük eğirme makinesinden 8 tanesinin Güney Doğu Anadolu Bölgesinde faaliyetini sürdürüyor olmasıdır.

${ }^{28}$ GTHB, Faal Ticari Firmalar Raporu 2016, GAP Bölgesi - (Gıda, Tarım ve Hayvancılık Bakanlığı). 


\section{Araştırmanın Metodolojisi}

\section{Amaç}

$\mathrm{Bu}$ araştırma, giysi tasarımında organik kumaşların kullanım durumunu belirlemek amacıyla yapılmıştır. Araştırmanın amacına ulaşabilmesi için aşağıda ki sorulara yanıt aranacaktır:

1) Organik kumaşları kullanan markalar kumaşları hangi firmalardan temin etmektedirler?

2) Organik tekstil koleksiyonu bulunan markalar ve bu marka müşterilerinin özellikleri nelerdir?

3) Organik tekstil alışverişi yapan tüketicilerin farkındalık durumu nedir?

4) Organik kumaşlardan yapılan tasarımların tercih edilme durumu nedir?

5) Organik giysi tasarımlarının pazar durumu nedir?

\section{Araştırmanın Modeli}

Giysi tasarımında organik kumaşların kullanım durumunu belirlemek amacıyla yapılan bu çalışma da tarama modeline dayalı betimsel yönlü bir araştırma kullanılacaktır. Tarama modeli, geçmiş yıllarda ya da günümüzdeki bir durumu olduğu gibi betimsel şekilde tasvir etmeyi amaçlayan araştırma metodudur. ${ }^{29}$ Betimsel anket araştırma sisteminin kullanıldığı tekniklere; anket, mülakat, gözlem şeklinde sınıflandırılmaktadır. Bu araştırma da giysi tasarımında organik kumaşların kullanım durumunun belirlenmesi amacıyla, organik kumaşlardan koleksiyon hazırlayan markaların görüşleri anket yöntemi kullanılarak belirlenmeye çalışılacaktır. Organik tekstil ürünlerini kullanan tüketicilerin görüşleri de anket yöntemi ile belirlenmeye çalışılacaktır. Yapılan bu çalışma literatür temelinde yapılmış, konuya dair Tarım ve Köy İşleri Bakanlığı'nın verileri, muhtelif yerli ve yabancı kitap ve makale, daha önceden yapılmış ve konuyla dolaylı veya doğrudan bağlantılı tez ve araştırmalar, organik tarıma ilişsin çıkarılmış yönetmelik ve tebliğler, internet yayınları kullanılarak toplanmıştır. Yöntem bağlamında incelenmiş olan yönetmeliklerin yorumlanması, kaynakların çeşitli yönleriyle değerlendirilerek sentezlenmesi, oran dağılımları ve

\footnotetext{
${ }^{29}$ Karasar, 1984,79
} 


\section{Organik Tekstil Ürünlerinin Pazar Yapısı}

yüzde değişimleri ile üretim, pazarlama ve dış ticaretteki gelişimlerin ortaya konması amaçlanmıştır.

\section{Araştırmanın Yöntemi}

Veri toplamak üzere anket uygulamasının gerçekleştirilmesi kararlaştırılmıştır. Literatür araştırmasından sonra sağlanan bilgiler doğrultusunda anket sorularının oluşturulmasına geçilecektir. Araştırmada yararlanılacak anket sorularının bir kısmı konuya dair araştırmalardan yararlanılarak, bir kısım sorular ise araştırmanın amaç, içerik ve anketin uygulanacağı ana kütle özellikleri göz önünde bulundurularak araştırmacının kendisince geliştirilecektir.

Uygulama anketini geliştirirken mülakatlardan elde edilen veriler ve pilot uygulamalar sonucunda gerekli maddelerin ilave edilmesi neticesinde ankete son hali verilmiştir. Kapsamlı biçimde ele alınabilecek bir araştırmaya rastlanamadığından Keşfedici bir araştırma yöntemi kullanılmıştır. Araştırmamızın ana kütlesi Türkiye'deki organik tekstilden üretilen ürünleri kullanan tüketicileri kapsamaktadır. Organik ürün tüketicisinin geniş çapta olmaması nedeniyle yerince tüketiciye ulaşılamamıştır. Bu nedenle, araştırmaya bağlı olarak, kararlı biçimde oluşturulan örneklemeyi meydana getiren unsurlar, araştıranın cevap bulacağını düşündüğü deneklerin rastgele seçilmesinden oluşan sistemin meydana getirilmesi önemli olacaktır. ${ }^{30}$ Organik Pazar olarak ürünlerin yoğunlaştığı Ankara ve İstanbul gibi 2 şehirde hem mağazaları hem de ürünü tüketeceklerin olması nedeniyle buraların doğru olduğuna karar verilmiştir. Oluşturulan örneklemdeki denekler kolayda örnekleme ile yapılmıştır.

Elde edilen veriler SPSS programında değerlendirilmiştir. Frekans dağılımları, faktör analizi, ttesti, ANOVA, Ki-kare şeklindeki analiz yöntemleriyle yorumlanacaktır.

\section{Evren ile Örneklem}

Araştırmanın evrenini kolay ulaşılabilir olması bakımından Ankara ve İstanbul ilinde bulunan organik tekstil ürünlerini kullanan tüketiciler ile markalar oluşturacaktır. Araştırmanın

\footnotetext{
${ }^{30}$ Büyüköztürk Ş.,Kılıç Çakmak, E,. Akgün, Ö.E., Karadeniz, Ş., Demirel, F., (2012) Bilimsel Araştırma Yöntemleri . 11.Baskı, Ankara: Pegem Akademi.
} 
örneklemini ise Ankara ve İstanbul ilinde bulunan üretici ve tüketicilerden tesadüfî örneklem yöntemi ile ulaşılabilen tüketiciler ile markalar oluşturacaktır. Üreticilerin ve tüketicilerin görüşlerini belirlemek amacıyla anket formu geliştirilecektir.

\section{Ölçme Araçları}

İngilizce açılımıyla: "Statistical Package for the Social Sciences" isimli ve 1968 y1lında ABD asılllı bir firma tarafında ilk olarak piyasaya sürülen SPSS programı kullanılarak yapılan bir istatistik sistemidir. 2010'dan itibaren resmen IBM SPSS istatistik şeklinde kullanılmaya başlamıştır. En son kullanılan sürüm IBM SPSS Statistics 22,0 programıdır $^{31}$.

\section{Ölçüm Güvenirliği}

Yapılan anketlere SSPSS 22 istatistiksel veri uygulanıp güvenirlik sonucu elde edilecektir. Ölçüm yorumları yapılan analizde çıkan tablolardaki güvenirliğe göre yapılacaktır. Kullanacağımız veri paketi sayesinde kullanım geçerliliğinin en çok \% 95 olacağı düşünülmektedir.

\section{Verilerin Toplanması}

$\mathrm{Bu}$ bölümde istenen verilere yayın, kitap, makale gibi materyaller incelenerek ulaşılacaktır. Uygulamada ise yöneticilerin bir kısmına amaç doğrultusunda yönlendirme yapılmış, bir kısmının kendi uygulamasına izin verilmiş, bilgilendirme ve yönlendirmenin etkisi değerlendirilmiştir.

\section{Verilerin Çözümlenmesi ve Yorumlanması}

Araştırmanın teorik kapsamında "Deneme Modeli" elde edilecek, bu veriler esas alınarak SPSS 22 istatistik anket programında yer alan sorular girilip gereken tablolar çıkartılacaktır. Çıkarılan tablolardan elde edilen veriler neticesinde yorum yapilacaktır.

\footnotetext{
${ }^{31}$ Wellman, 1996: 78
} 


\section{Varsayımlar/ Sayıltılar}

1) Kaynak kişilerle yapılan görüşmelerden elde edilen bilgiler amaca hizmet edecek nitelikte ve yeterliliktedir.

2) Kaynak kişiler ölçme araçlarına içten ve doğru cevaplar vermiştir.

3)Seçilen araştırma yönteminin, araştırmanın sonucuna ulaşmada yeterli olduğu düşünülmektedir.

\section{Sinırlılıklar}

1) Araştırma organik kumaşları üreten firmalar ve organik kumaşlardan giysi tasarımı yapan markalar ile sınırlandırılmıştır.

2) Araştırma organik tekstili kullanan tüketiciler ile sınırlandırılmıştır.

3) Ankara ve İstanbul ilinde bulunan firmalar ve tüketiciler ile sınırlandırılmıştır.

\section{Elde Edilen Verilerin Analizinin Yapılma Yöntemleri}

Yaptığımız bu çalışmadaki veriler SPSS 22,0 programı dahilinde analizleri gerçekleştirilmiştir. Yine değerlendirme sürecinde tanımlayıcı istatistiki yöntemlerinin kullanılmasıyla ulaşılmıştır. Bu bulgulardan \%95 güven ile \%5 anlamlılık değerleri arasında olduğuna ulaşılmıştır. Tutum düzeyi puanı ölçekteki sorulara verilen cevapların değerlendirilmesiyle elde edilmiştir. Demografik değişkenlerde yaş, cinsiyet eğitim ile medeni durum değerleri kullanılmıştır. Organik giysi tasarımında üreticilerin ve tüketicilerin genel özelliklerine ait frekans analizleri Tablo 1'de gösterilmiştir.

Tablo 1: Demografik Özellikler

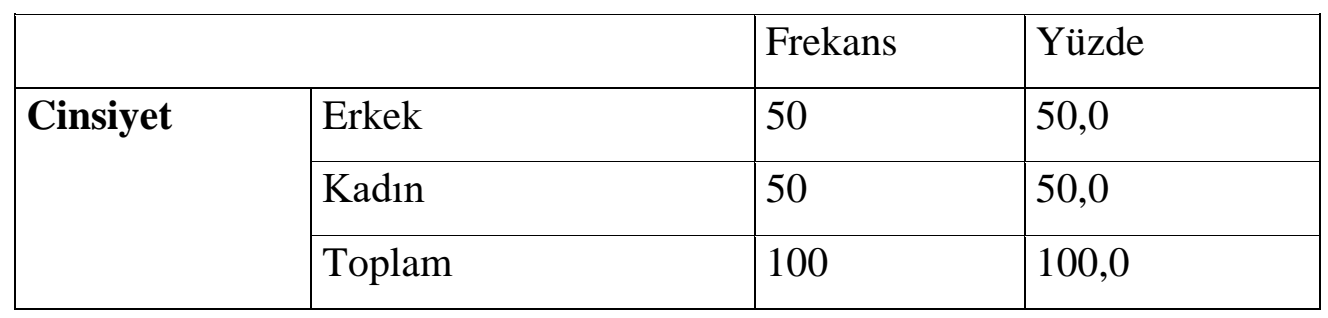




\begin{tabular}{|c|c|c|c|}
\hline \multirow[t]{6}{*}{ Yaş } & $18-25$ & 17 & 17,0 \\
\hline & $25-32$ & 40 & 40,0 \\
\hline & $32-39$ & 36 & 36,0 \\
\hline & $39-46$ & 5 & 5,0 \\
\hline & 46 ve üstü & 2 & 2,0 \\
\hline & Toplam & 100 & 100,0 \\
\hline \multirow{3}{*}{$\begin{array}{l}\text { Medeni } \\
\text { Durum }\end{array}$} & Evli & 77 & 77,0 \\
\hline & Bekar & 23 & 23,0 \\
\hline & Toplam & 100 & 100,0 \\
\hline \multirow[t]{6}{*}{ Meslek } & Öğrenci & 18 & 18,0 \\
\hline & Ev hanımı & 22 & 22,0 \\
\hline & İşçi & 23 & 23,0 \\
\hline & Serbest Meslek & 21 & 21,0 \\
\hline & Diğer & 6 & 6,0 \\
\hline & Toplam & 100 & 100,0 \\
\hline \multirow[t]{7}{*}{ Ĕgitim Düzeyi } & İlköğretim & 1 & 1,0 \\
\hline & Orta Öğretim & 8 & 8,0 \\
\hline & Ön Lisans & 12 & 12,0 \\
\hline & Lisans & 56 & 56,0 \\
\hline & Y. Lisans & 20 & 20,0 \\
\hline & Doktora & 3 & 3,0 \\
\hline & Toplam & 100 & 100,0 \\
\hline \multirow[t]{8}{*}{ Aylık Gelir } & 1500 TL alt1 & 10 & 10,0 \\
\hline & $1500-2000 \mathrm{TL}$ & 34 & 34,0 \\
\hline & $2000-3000 \mathrm{TL}$ & 27 & 27,0 \\
\hline & $3000-4000 \mathrm{TL}$ & 13 & 13,0 \\
\hline & $4000-5000 \mathrm{TL}$ & 4 & 4,0 \\
\hline & 5000 TL ve üstü & 12 & 12,0 \\
\hline & Toplam & 100 & 100,0 \\
\hline & 250 TL alt 1 & 15 & 15,0 \\
\hline
\end{tabular}




\begin{tabular}{|l|l|l|l|}
\hline \multirow{3}{*}{$\begin{array}{l}\text { Aylık giyim } \\
\text { alışverişine } \\
\text { harcadığınız } \\
\text { tutar }\end{array}$} & $250-500 \mathrm{TL}$ & 31 & 31,0 \\
\cline { 2 - 4 } & $500-750 \mathrm{TL}$ & 23 & 23,0 \\
\cline { 2 - 4 } & $750-1000 \mathrm{TL}$ & 11 & 11,0 \\
\cline { 2 - 4 } & $1000-1500 \mathrm{TL}$ & 12 & 12,0 \\
\cline { 2 - 4 } & $1500 \mathrm{TL}$ ve üstü & 8 & 8,0 \\
\cline { 2 - 4 } & Toplam & 100 & 100,0 \\
\hline
\end{tabular}

Müşteri katılımcıların \%50'si erkek \% 50'si kadındır. \%40'1 25-32 yaş, \%36'sı ise 32-39 yaş arasındadır. \%77'si evli, \%23'ü ise bekârdır. \%22'si ev hanımı \%23'ü işçi, \%21'i serbest meslek çalışanıdır. \%56'sı lisans, \%20'si Y. lisans mezunudur. \%34'ü 1500-2000 TL, \%27'si 2000-3000 TL, \%13'ü 3000-4000 TL arası gelire sahiptir. \%31'i 250-500 TL aras1, \%23'ü ise 500-750 TL arası aylık giyim alışverişine harcadığı tutar vardır.

Giyinme konusunda kendinizi hangi grup içinde görürsünüz

\begin{tabular}{|c|c|c|c|}
\hline & & Frekans & Yüzde \\
\hline $\begin{array}{l}\text { Giyinme konusunda } \\
\text { kendinizi hangi grup }\end{array}$ & $\begin{array}{l}\text { Modayı çok yakından takip eden ve } \\
\text { uygulayan }\end{array}$ & 35 & 35,0 \\
\hline \multirow[t]{3}{*}{ içinde görürsünüz } & $\begin{array}{l}\text { Modayı takip etmeye ve uygulamaya } \\
\text { çalışan }\end{array}$ & 34 & 34,0 \\
\hline & $\begin{array}{l}\text { Modayla ilgilenmeyen ve alışık olduğu } \\
\text { giysileri giyen }\end{array}$ & 31 & 31,0 \\
\hline & Toplam & 100 & 100 \\
\hline
\end{tabular}

Katılımcıların giyinme konusunda kendinizi hangi grup içinde görürsünüz sorusuna verilen cevaplar \%35'i modayı çok yakından takip eden ve uygulayan, \%34'ü modayı takip etmeye ve uygulamaya çalışan, \%31'i modayla ilgilenmeyen ve alışı olduğu giysileri giyen cevabı verdiği görülmüştür. 


\section{Organik Giysi Koleksiyonu Bulunan Markalar Hakkındaki Görüşleriniz Nelerdir?}

\begin{tabular}{|l|l|l|l|l|l|l|}
\hline Görüşler & \multicolumn{2}{l}{ Evet } & \multicolumn{2}{l}{ Hayır } & \multicolumn{2}{l|}{ Kımen } \\
\hline & $\mathrm{f}$ & $\%$ & $\mathrm{f}$ & $\%$ & $\mathrm{f}$ & $\%$ \\
\hline $\begin{array}{l}\text { Organik giyim üretimi yapan marka sayısı } \\
\text { yeterlidir. }\end{array}$ & 26 & $\% 26,0$ & 57 & $\% 57,0$ & 17 & $\% 17,0$ \\
\hline $\begin{array}{l}\text { Organik kumaşlardan koleksiyon hazırlayan } \\
\text { markaların tasarımları yeterlidir. }\end{array}$ & 32 & $\% 32,0$ & 43 & $\% 43,0$ & 25 & $\% 25,0$ \\
\hline $\begin{array}{l}\text { Organik kumaşlardan koleksiyon hazırlayan } \\
\text { markaların reklam ve tanıtımı yeterlidir. }\end{array}$ & 26 & $\% 26,0$ & 47 & $\% 47,0$ & 27 & $\% 27,0$ \\
\hline $\begin{array}{l}\text { Organik kumaşlardan koleksiyon hazırlayan } \\
\text { markaların çevreye ve insan sağlığına önem }\end{array}$ & 48 & $\% 48,0$ & 19 & $\% 19,0$ & 33 & $\% 33,0$ \\
verdiklerini düşünüyorum. & 51 & $\% 51,0$ & 13 & $\% 13,0$ & 36 & $\% 36,0$ \\
\hline $\begin{array}{l}\text { Organik kumaşlardan koleksiyon hazırlayan } \\
\text { markalar, tüketicilerin talepleri doğrultusunda } \\
\text { koleksiyonlarını hazırlamaktadırlar. }\end{array}$ & & & & & & \\
\hline
\end{tabular}

Müşterilerin organik kumaşlardan koleksiyon hazırlayan markalar hakkındaki görüşleri sorulduğunda, organik kumaşlardan koleksiyon hazırlayan markaların tasarımlarının yeterli olup olmadığı hususunda \%32'si evet, \%43'ü hayır, \%25'i kısmen cevabı vermiştir.

Organik kumaşlardan koleksiyon hazırlayan markaların reklam ve tanıtımının yeterli olup olmadığı hususunda \%26'sı evet, \%47'si hayır, \%27'si kısmen cevabı vermiştir.

Organik kumaşlardan koleksiyon hazırlayan markaların çevreye ve insan sağlığına önem verdiklerini düşünüp düşünmedikleri hususunda \%48'i evet, \%19'u hayır, \%33'ü kısmen cevabı vermiştir. Organik kumaşlardan koleksiyon hazırlayan markaların, tüketicilerin talepleri doğrultusunda koleksiyonlarını hazırlayıp hazırlamadıkları hususunda \%51'i evet, \%13'ü hayır, \%36’sı kısmen cevabı vermiştir. 


\section{Organik Giysi Tasarımlarını Tüketicilerin Satın Alma Davranışları Nelerdir?}

\begin{tabular}{|c|c|c|c|}
\hline & & Frekans & Yüzde \\
\hline \multirow{5}{*}{$\begin{array}{l}\text { Giysilerinizi nereden } \\
\text { satın almaktasınız }\end{array}$} & Alışveriş merkezlerinden & 63 & 23,00 \\
\hline & İnternet mağazacılığından & 28 & 28,00 \\
\hline & $\begin{array}{l}\text { Hem internet mağazacılığından hem de } \\
\text { alışveriş merkezlerinden }\end{array}$ & 8 & 8,00 \\
\hline & Diğer & 1 & 1,00 \\
\hline & Toplam & 100 & 100 \\
\hline
\end{tabular}

Katılımcıların giysilerinizi nereden satın almaktasınız sorusuna verdikleri cevaplar \%63’ü Alışveriş merkezlerinden, \%28'i internet mağazacılığından, \%8'i hem internet mağazacılı̆̆ından hem de alışveriş merkezlerinden cevabı verdiği görülmüştür.

Giysi Satın Alırken Nelere Dikkat Edersiniz?

\begin{tabular}{|l|l|l|l|l|l|l|l|l|l|l|}
\hline Dikkat Edilen Hususlar & \multicolumn{2}{l}{ Her zaman } & \multicolumn{2}{l}{ Sıklıkla } & \multicolumn{3}{l|}{ Bazen } & \multicolumn{2}{l|}{ Nadiren } & \multicolumn{2}{l|}{ Hiçbir } \\
& f & $\%$ & f & $\%$ & f & $\%$ & f & $\%$ & f & $\%$ \\
\hline $\begin{array}{l}\text { Giysinin organik kumaştan } \\
\text { üretilmiş olmasına }\end{array}$ & 36 & $\% 36,0$ & 18 & $\% 18,0$ & 44 & $\% 44,0$ & 2 & $\% 2,0$ & - & - \\
\hline $\begin{array}{l}\text { Giyside kullanılan kumaşın } \\
\text { kalitesine }\end{array}$ & 56 & $\% 56,0$ & 11 & $\% 11,0$ & 25 & $\% 25,0$ & 8 & $\% 2,0$ & - & - \\
\hline Giysinin model özelliklerine & 42 & $\% 42,0$ & 33 & $\% 33,0$ & 15 & $\% 15,0$ & 10 & $\% 10,0$ & - & - \\
\hline Giysinin dikim kalitesine & 31 & $\% 31,0$ & 30 & $\% 30,0$ & 20 & $\% 20,0$ & 15 & $\% 15,0$ & 4 & $\% 4,0$ \\
\hline Giysinin fiyatına & 68 & $\% 68,0$ & 31 & $\% 31,0$ & 1 & $\% 1,0$ & - & - & - & - \\
\hline Giysinin rahatlı̆̆ına & 53 & $\% 53,0$ & 28 & $\% 28,0$ & 19 & $\% 19,0$ & - & - & - & - \\
\hline $\begin{array}{l}\text { Giysinin hammadde ve kullanım } \\
\text { etiketine }\end{array}$ & 57 & $\% 57,0$ & 32 & $\% 32,0$ & 10 & $\% 10,0$ & 1 & $\% 1,0$ & - & - \\
\hline
\end{tabular}


Katılımcıların Giysi satın alırken organik kumaştan üretilmiş olmasına sorusuna \%36'sı her zaman, \%18'i sıklıkla, \%44'ü bazen, \%2'si de nadiren cevabı verdiği görülmüştür.

Katılımcıların Giyside kullanılan kumaşın kalitesine sorusuna \%56'sı her zaman, \%11'i sıklıkla, \%25'i bazen, \%8'i de nadiren cevabı verdiği görülmüştür. Katılımcıların Giysinin model özelliklerine sorusuna \%42'si her zaman, \%33'ü sıklıkla, \%15'i bazen, \%10’u da nadiren cevab1 verdiği görülmüştür. Katılımcıların Giysinin dikim kalitesine sorusuna \%31'i her zaman, \%30’u sıklıkla, \%20'si bazen, \%15'i nadiren, \%4’ü hiçbir zaman cevabı verdiği görülmüştür. Katılımcıların Giysinin fiyatına sorusuna \%68'i her zaman, \%31'i sıklıkla, \%1'i bazen cevabı verdiği görülmüştür. Katılımcıların Giysinin rahatlığına sorusuna \%53’ü her zaman, \%28'i sıklıkla, \%19'u bazen cevabı verdiği görülmüştür. Katılımcıların Giysinin hammadde ve kullanım etiketine sorusuna \%57'si her zaman, \%32'si s1kl1kla, \%10'u bazen, \%1'i de nadiren cevab1 verdiği görülmüştür.

\section{Organik Kumaşlardan Yapılmış Giysileri Satın Alma Davranışınız}

\begin{tabular}{|c|c|c|c|}
\hline & Frekans & Yüzde \\
\hline \multirow{7}{*}{$\begin{array}{l}\text { Organik kumaşlardan } \\
\text { yapılmış giysileri satın } \\
\text { alma davranışınız } \\
\text { aşağıdakilerden } \\
\text { hangisidir? }\end{array}$} & $\begin{array}{l}\text { Organik giysiler hakkında bilgi } \\
\text { sahibiyim, özellikle organik giysileri } \\
\text { tercih ederim }\end{array}$ & 14 & $\% 14,0$ \\
\hline & $\begin{array}{l}\text { Tesadüfen denk geldiğimde Organik } \\
\text { giysileri tercih ederim }\end{array}$ & 21 & $\% 21,0$ \\
\hline & $\begin{array}{l}\text { Giysilerdeki etiketleri okurum özellikle } \\
\text { organik olanları tercih ederim }\end{array}$ & 11 & $\% 11,0$ \\
\hline & $\begin{array}{l}\text { Organik giysileri daha çok çocuk } \\
\text { giysilerinde tercih ederim }\end{array}$ & 35 & $\% 35,0$ \\
\hline & $\begin{array}{l}\text { Organik giysileri daha çok iç giyimde } \\
\text { tercih ederim }\end{array}$ & 18 & $\% 18,0$ \\
\hline & Diğger & 1 & $\% 1,0$ \\
\hline & Toplam & 100 & 100 \\
\hline
\end{tabular}

Katılımcıların organik kumaşlardan yapılmış giysileri satın alma davranışları ile ilgili verdikleri cevaplara göre \%14'ü organik giysiler hakkında bilgi sahibiyim, özellikle organik giysileri tercih 
ederim, \%21'i tesadüfen denk geldiğimde organik giysileri tercih ederim, \%11'i giysilerdeki etiketleri okurum özellikle organik olanları tercih ederim, \%35'i organik giysileri daha çok çocuk giysilerinde tercih ederim, $\% 18$ 'i organik giysileri daha çok iç giyimde tercih ederim cevabı verdikleri görülmüştür.

\section{Organik Kumaş Kullanımının Çevreye Ve İnsana Sağladığı Katkılar}

\begin{tabular}{|l|l|l|l|l|l|l|}
\hline & \multicolumn{2}{|l|}{ Katılmıyorum } & \multicolumn{2}{l|}{$\begin{array}{l}\text { Kısmen } \\
\text { Katılmıyorum }\end{array}$} & \multicolumn{2}{l|}{ Katılıyorum } \\
\hline & $\mathrm{f}$ & $\%$ & $\mathrm{f}$ & $\%$ & $\mathrm{f}$ & $\%$ \\
\hline $\begin{array}{l}\text { Organik kumaştan üretilen giysileri } \\
\text { tercih eden insanların hayata bakışı } \\
\text { pozitiftir. }\end{array}$ & 62 & $\% 62,0$ & 21 & $\% 21,0$ & 17 & $\% 17,0$ \\
\hline $\begin{array}{l}\text { Organik tekstil ürünleri kullanan } \\
\text { insanlar çevre kirliliğine duyarlıdır. }\end{array}$ & 25 & $\% 25,0$ & 26 & $\% 27,0$ & 49 & $\% 49,0$ \\
\hline $\begin{array}{l}\text { Organik tekstil ürünlerin kullanılması } \\
\text { son yıllarda bozulan ekolojik dengenin } \\
\text { düzelmesine katkı sağlar. }\end{array}$ & 68 & $\% 68,0$ & 29 & $\% 29,0$ & 3 & $\% 3,0$ \\
\hline $\begin{array}{l}\text { Organik ürünlerin kullanımının } \\
\text { yaygınlaşması gelecek nesillere daha } \\
\text { temiz bir çevre sunmamızı sağlar. }\end{array}$ & 31 & $\% 31,0$ & 32 & $\% 32,0$ & 37 & $\% 37,0$ \\
\hline
\end{tabular}

Müşterilerin organik kumaş kullanımının çevreye ve insana sağladığı katkılar hakkındaki görüşleri sorulduğunda; Organik kumaştan üretilen giysileri tercih eden insanların hayata bakışının pozitif olup olmadığı hususunda \%62'si katılmıyorum, \%21'i kısmen katılmıyorum, \%17'si katılıyorum cevabı vermiştir. Organik tekstil ürünleri kullanan insanların çevre kirliliğine duyarlı olup olmadığı hususunda \%25'i katılmıyorum, \%26'sı kısmen katılmıyorum, \%49'u katıllyorum cevabı vermiştir. Organik tekstil ürünlerin kullanılması son yıllarda bozulan ekolojik dengenin düzelmesine katkı sağlayıp sağlamadığı hususunda \%68'i katılmıyorum, \%29'u kısmen katılmıyorum, \%3'ü katılıyorum cevabı vermiştir. Organik ürünlerin kullanımının yaygınlaşması gelecek nesillere daha temiz bir çevre sunmamızı sağlayıp sağlamadığı hususunda \%31'i katılmıyorum, \%32'si kısmen katılmıyorum, \%37'si katıllyorum cevabı vermiştir. 


\section{Organik Giysi Tasarımlarında Yaşadığınız Sorunlar Hakkındaki Görüşleriniz.}

\begin{tabular}{|c|c|c|c|c|c|c|}
\hline \multirow[t]{2}{*}{ Sorunlar } & \multicolumn{2}{|c|}{ Katılıyorum } & \multicolumn{2}{|c|}{$\begin{array}{l}\text { Kismen } \\
\text { Katıliyorum }\end{array}$} & \multicolumn{2}{|c|}{ Katılmıyorum } \\
\hline & $\mathbf{f}$ & $\%$ & f & $\%$ & $\mathbf{f}$ & $\%$ \\
\hline $\begin{array}{l}\text { Organik giysi fiyatlarının yüksek } \\
\text { olması }\end{array}$ & 61 & $\% 61,0$ & 37 & $\% 37,0$ & 2 & $\% 2,0$ \\
\hline $\begin{array}{l}\text { Organik kumaşlardan yapılmış giysi } \\
\text { modellerinin sınırlı olması }\end{array}$ & 42 & $\% 42,0$ & 36 & $\% 36,0$ & 22 & $\% 22,0$ \\
\hline $\begin{array}{l}\text { Organik giysileri üreten markaların } \\
\text { sinırlı olması }\end{array}$ & 44 & $\% 44,0$ & 40 & $\% 40,0$ & 1 & $\% 1,0$ \\
\hline $\begin{array}{l}\text { Organik giysilerde kullanılan renklerin } \\
\text { sinırlı olması }\end{array}$ & 23 & $\% 23,0$ & 21 & $\% 21,0$ & 56 & $\% 56,0$ \\
\hline $\begin{array}{l}\text { Organik giysi tasarımlarının kolay } \\
\text { ulaşılabilirliğinin olmaması }\end{array}$ & 39 & $\% 39,0$ & 31 & $\% 31,0$ & 30 & $\% 30,0$ \\
\hline $\begin{array}{l}\text { Tasarımlarda kullanılan yardımcı } \\
\text { malzemelerin organik olmaması }\end{array}$ & 38 & $\% 38,0$ & 30 & $\% 30,0$ & 32 & $\% 32,0$ \\
\hline
\end{tabular}

Müşterilerin organik giysi tasarımlarında yaşadığınız sorunlar hakkındaki görüşleri sorulduğunda; Organik giysi fiyatlarının yüksek olması hususunda \%2'si katılmıyorum, \%37'si kısmen katılıyorum, \%61'i katılıyorum cevabı vermiştir. Organik kumaşlardan yapılmış giysi modellerinin sınırlı olup olmadığı hususunda \%22'si katılmıyorum, \%36'sı kısmen katılıyorum, \%42'si katılıyorum cevabı vermiştir. Organik giysileri üreten markaların sınırlı olması hususunda \%1'i katılmıyorum, \%40’1 kısmen katılıyorum, \%44’ü katılıyorum cevabı vermiştir. Organik giysilerde kullanılan renklerin sınırlı olması hususunda \%56's1 katılmiyorum, \%21'i kısmen katılıyorum, \%23'ü katılıyorum cevabı vermiştir. Organik giysi tasarımlarının kolay ulaşılabilirliğinin olmaması hususunda \%30'u katılmıyorum, \%31'i kısmen katılıyorum, \%39'u katılıyorum cevabı vermiştir. Tasarımlarda kullanılan yardımcı malzemelerin organik olmaması hususunda \%32'si katılmıyorum, \%30’u kısmen katılıyorum, \%38'i katılıyorum cevabı vermiştir. Giysi tasarımında organik kumaşların kullanımı ile ilgili beklentileriniz. 


\begin{tabular}{|c|c|c|c|c|c|c|}
\hline \multirow[t]{2}{*}{ Beklentiler } & \multicolumn{2}{|c|}{ Katılıyorum } & \multicolumn{2}{|c|}{\begin{tabular}{|l|} 
Kismen \\
Katıllyorum
\end{tabular}} & \multicolumn{2}{|c|}{ Katılmıyorum } \\
\hline & $\mathbf{f}$ & $\%$ & f & $\%$ & f & $\%$ \\
\hline $\begin{array}{l}\text { Her markanın koleksiyonunda Organik } \\
\text { Giysiler bulunmalıdır }\end{array}$ & 62 & $\% 62,0$ & 38 & $\% 38,0$ & - & - \\
\hline $\begin{array}{l}\text { Organik giysilerle ilgili ülke stratejisi } \\
\text { oluşturulmalıdır }\end{array}$ & 41 & $\% 41,0$ & 36 & $\% 36,0$ & 23 & $\% 23,0$ \\
\hline $\begin{array}{l}\text { Organik Giysilerde model çeşitliliğine } \\
\text { gidilmelidir }\end{array}$ & 51 & $\% 51,0$ & 32 & $\% 32,0$ & 17 & $\% 17,0$ \\
\hline $\begin{array}{l}\text { Ekolojik denge ve insan sağlı̆̆ı için } \\
\text { organik giysiler yaygın olarak } \\
\text { kullanılmalıdır }\end{array}$ & 33 & $\% 33,0$ & 30 & $\% 30,0$ & 37 & $\% 37,0$ \\
\hline $\begin{array}{l}\text { Organik giysilere fiyat yapılandırılmas1 } \\
\text { uygulanmalıdır }\end{array}$ & 47 & $\% 47,0$ & 40 & $\% 40,0$ & 13 & $\% 13,0$ \\
\hline
\end{tabular}

Müşterilerin giysi tasarımında organik kumaşların kullanımı ile ilgili beklentileri sorulduğunda;

Her markanın koleksiyonunda organik giysiler bulunması hususunda \%38'i k1smen katılıyorum, \%62'si katılıyorum cevabı vermiştir. Organik giysilerle ilgili ülke stratejisi oluşturulması hususunda \%23'ü katılmıyorum, \%36'sı kısmen katılıyorum, \%41'i kat1lıyorum cevabı vermiştir. Organik giysilerde model çeşitliliğine gidilmesi hususunda \%17'si katılmıyorum, \%32'si kısmen katılıyorum, \%51'i katılıyorum cevabı vermiştir. Ekolojik denge ve insan sağlığı için organik giysiler yaygın olarak kullanılmalıdır hususunda \%37'si katılmıyorum, \%30'u kısmen katılıyorum, \%33'ü katılıyorum cevabı vermiştir. Organik giysilere fiyat yapılandırılması

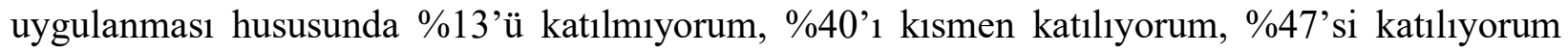
cevabı vermiştir.

Organik giysi tasarımında üreticilerin ve tüketicilerin özellikleri nelerdir?

\begin{tabular}{|l|l|l|l|}
\hline \multicolumn{2}{|c|}{} & Frekans & Yüzde \\
\hline İşletmeniz kaç & $1-5$ yıl & 1 & 6,7 \\
\cline { 2 - 4 } yıldır giyim & $6-10$ yıl & 3 & 20,0 \\
\hline
\end{tabular}




\begin{tabular}{|c|c|c|c|}
\hline \multirow{5}{*}{$\begin{array}{l}\text { sektöründe } \\
\text { üretim } \\
\text { yapmaktadır? }\end{array}$} & $11-15$ y1l & 6 & 40,0 \\
\hline & $16-20$ y1l & 2 & 13,3 \\
\hline & $21-25$ y1l & 2 & 13,3 \\
\hline & 25 yll ve üstü & 1 & 6,7 \\
\hline & Toplam & 15 & 100,0 \\
\hline \multirow{7}{*}{$\begin{array}{l}\text { İşletmeniz kaç } \\
\text { yıldır organik } \\
\text { kumaşları } \\
\text { kullanarak } \\
\text { üretim } \\
\text { yapmaktadır? }\end{array}$} & 1- $5 \mathrm{y} 11$ & 11 & 73,3 \\
\hline & 6- 10 y1l & 3 & 20,0 \\
\hline & $11-15$ y1l & 1 & 6,7 \\
\hline & $16-20$ y1l & - & - \\
\hline & $21-25$ y1l & - & - \\
\hline & 25 y1l ve üstü & - & - \\
\hline & Toplam & 15 & 100,0 \\
\hline \multirow{6}{*}{$\begin{array}{l}\text { İşletmenizin } \\
\text { faaliyette } \\
\text { bulunduğu şehir? }\end{array}$} & Ankara & 3 & 20,0 \\
\hline & İstanbul & 8 & 53,3 \\
\hline & İzmir & - & - \\
\hline & Eskişehir & 4 & 26,7 \\
\hline & Diğer & - & - \\
\hline & Toplam & 15 & 100,0 \\
\hline \multirow{5}{*}{$\begin{array}{l}\text { İşletmenizin } \\
\text { giyim } \\
\text { sektöründeki } \\
\text { pazarı nedir? }\end{array}$} & İç Pazar & 5 & 33,3 \\
\hline & Dış Pazar & 1 & 6,7 \\
\hline & İç ve Dış Pazar & 9 & 60,0 \\
\hline & Diğer & - & - \\
\hline & Toplam & 15 & 100,0 \\
\hline \multirow{6}{*}{$\begin{array}{l}\text { İşletmenizde } \\
\text { yapılan giysi } \\
\text { tasarımları } \\
\text { koleksiyonlarını } \\
\text { n \% kaçını } \\
\text { organik } \\
\text { kumaşlardan }\end{array}$} & $\begin{array}{l}\text { Hiç organik kumaştan yapılan } \\
\text { tasarım bulunmamaktadır. }\end{array}$ & & - \\
\hline & $\% 1-5$ & - & - \\
\hline & $\% 6-10$ & - & - \\
\hline & $\% 11-15$ & 5 & 33,3 \\
\hline & $\% 16-20$ & 9 & 60,0 \\
\hline & $\% 20$ ve üstü & 1 & 6,7 \\
\hline
\end{tabular}




\begin{tabular}{|l|l|l|l|}
\hline $\begin{array}{l}\text { yapılan } \\
\text { tasarımlar }\end{array}$ & Toplam & \\
oluşturmaktadır & & 15 & 100,0 \\
$?$ & & & \\
\hline
\end{tabular}

İşletmelerin \%6,7'si 1- 5 yı1, \%20’si 6- 10 y11, \% 40’1 11 - 15 yıl , \%13,3’ü 16 - 20 yı1 , \%13,3’ü $21-25$ yıl ve \%6,7'si 25 y1l ve üstü süre giyim sektöründe üretim yapmaktadır.

İşletmelerin \%73,3’ü 1- 5 yı1, \%20'si 6- 10 y1l, \% 6,7'si 11 - 15 yı1 yıldır organik kumaşları kullanarak üretim yapmaktadır. İşletmelerin \%20'si Ankara, \%53,3'ü İstanbul, \%26,7'si Eskişehir ilinde faaliyettedirler.İşletmelerin \%33,3'ü iç pazar, \%6,7'si dış dazar, \%60'1 ise hem iç hem diş pazar alalarında faaliyet göstermektedir.İşletmelerin \%33,3'ünde yapılan giysi tasarımları koleksiyonlarının \%11-15'i, \%60'ında yapılan giysi tasarımları koleksiyonlarının \%16-20'si, $\% 6,7$ 'sinde yapılan giysi tasarımları koleksiyonlarının \%20 ve üstü oranda organik kumaşlardan yapılan tasarımlar bulunmaktadır.

\section{Organik Kumaşlardan Yapılan Tasarımların, İşletmenizde Yapılan Diğer Tasarımlara Göre Tüketiciler Açısından Tercih Edilme Durumu}

\begin{tabular}{|c|c|c|c|c|c|}
\hline $\begin{array}{l}\text { İşletme } \\
\text { No }\end{array}$ & $\begin{array}{l}\text { Tüketiciler bu } \\
\text { konuda seçici } \\
\text { değillerdir. } \\
(\%)\end{array}$ & $\begin{array}{l}\text { Tercih } \\
\text { edilmekte } \\
(\%)\end{array}$ & $\begin{array}{l}\text { Tercih } \\
\text { edilmemekte } \\
(\%)\end{array}$ & $\begin{array}{l}\text { Kismen tercih } \\
\text { edilmekte } \\
(\%)\end{array}$ & $\begin{array}{l}\text { Diğer } \\
(\%)\end{array}$ \\
\hline 1 & 12 & 51 & 9 & 23 & 5 \\
\hline 2 & 31 & 18 & 21 & 22 & 8 \\
\hline 3 & 33 & 31 & 20 & 10 & 6 \\
\hline 4 & 15 & 41 & 14 & 29 & 1 \\
\hline 5 & 30 & 22 & 25 & 13 & 10 \\
\hline
\end{tabular}




\begin{tabular}{|l|l|l|l|l|l|}
\hline 6 & 34 & 35 & 21 & 10 & 0 \\
\hline 7 & 22 & 23 & 42 & 11 & 2 \\
\hline 8 & 13 & 41 & 11 & 30 & 5 \\
\hline 9 & 11 & 51 & 13 & 25 & 0 \\
\hline 10 & 6 & 65 & 9 & 13 & 7 \\
\hline 11 & 16 & 21 & 55 & 8 & 0 \\
\hline 12 & 21 & 21 & 37 & 15 & 6 \\
\hline 13 & 27 & 12 & 23 & 33 & 5 \\
\hline 14 & 23 & 59 & 16 & 2 & 0 \\
\hline 15 & 10 & 11 & 70 & 9 & 0 \\
\hline
\end{tabular}

Organik kumaşlardan yapılan tasarımların, işletmenizde yapılan diğer tasarımlara göre tüketiciler açısından tercih edilme durumu incelendiğinde 4 firmada tercih edilme durumunun \%50 den fazladan olduğu görülmektedir. Genel olarak incelendiğinde organik kumaşlardan yapılan tasarımların tercih edildiği görülmektedir.

\section{Sonuç ve Öneriler}

Yapılan çalışmaya katılan müşterilerin yarısı erkek, yarısı kadındır. Yarıya yakını 25-32 yaş aralığındadır. Büyük çoğunluğu evlidir. Yarıdan fazlası Lisans mezunudur, yarıya yakını 1.5002.000 TL arası gelire sahiptir. Yine yarıya yakını 250-500 TL arası aylık giyim alışverişine harcama yaptığı görülmüştür. Müş̧erilerin yarıya yakını kendisini giyim konusunda modayı çok yakından takip eden ve uygulayan bir kişi olarak görmektedir. Yarısı organik kumaşlardan koleksiyon hazırlayan markaların çevreye ve insan sağlığına önem verdiklerini düşünmektedir. Müşterilerin çoğunluğu giysilerini alışveriş merkezlerinden satın almaktadır. Yine müşterilerin çoğu giyim alışverişi yaparken giysinin fiyatına, rahatlığına, hammadde ve kullanım etiketine dikkat etmektedirler. Yarıya yakını organik giysileri daha çok çocuk giysilerinde tercih etmektedir. 


\section{Organik Tekstil Ürünlerinin Pazar Yapısı}

Müşterilerin yine çoğunluğu organik tekstil ürünlerin kullanılmasının son yıllarda bozulan ekolojik dengenin düzelmesine katkı sağlayacağını düşünmektedir. Aynı zamanda müşterilerin çoğunluğu organik giysi fiyatlarının yüksek olmasının organik giysi tasarımlarında yaşanılanları temel sorun olarak görmektedir. Aynı zamanda, çoğunluğu her markanın koleksiyonunda organik giysiler bulunması gerektiğini düşünmektedir.

Akgüngör ve ark. 2010 yılı döneminde İstanbul ile İzmir illerinde yapmış oldukları bir araştırma neticesinde kentsel bölgede bulunan tüketicilerin organik malzemeyi seçiyor olmasına verdiği cevap, bu ürünlerin sağlık açısından risk faktörlerini daha az taşıyor oluşudur. Tüketiciler açısından organik ürünler benzerlerine göre daha pahalıdır fakat yine de bu ürünlere \%36 ya kadar fazla olacak şekilde ödeme yapmaya razı oldukları da görülmektedir.

Hassan ve Ark. 2009 yılında yaptıkları araştırmada tüketici tercihinde gelir, yaş ve hane halkı sayısının etkili olmadığı, eğitim seviyesinin ise etkili faktör olmasıdır. Uzlaşmacı şekilde benzerlerinin dışında organik malzemelerin kıllanılmasını sağlamaktadır.

Akgüngör ve Ark 2009 yılında yaptıkları bir araştırmada Ankara, İzmir ve İstanbul'da bulunan tüketici kesiminin \%8,7'si organik bazlı tekstil malzemelerinden yeterince haberdardır. Gelir düzeyi yüksek olan iç piyasadaki tüketiciler organik malzemeleri alma konusunda potansiyel bulundurmaktadir.

Ergin ve Özsaçmacı 2011 yılında yapıkları bir araştırmada İstanbul ile Ankara şehirlerindeki tüketicinin organik tekstil malzemelerini almasındaki asıl neden, ürünün diğerlerine göre daha sağlıkl1, rahat ve çevre dostu olduğunun düşünülmesidir. Üreticilerin büyük çoğunluğu organik kumaşlardan üretilen tasarımlar tercih eden kullanıcıların yüksek kalite beklentisi olan tüketicilerden olduğunu belirtmiştir. Yapılan çalışmaya katılan üreticilerin yaptığı işlemlerin yaklaşık yarısı 11 - 15 yıl süre olacak şekilde giyim sektöründe üretim yapmaktadırlar. İşletmelerin büyük çoğunluğu 1 - 5 yıl aralığında organik kumaşları kullanarak üretim yapmaktadır. İşletmelerin yarıdan fazlası yine İstanbul ilinde faaliyette bulunmaktadırlar. İşletmelerin yarıdan fazlası hem iç hem dış pazar alalarında faaliyet göstermektedir. İşletmelerin yarıdan fazlası yaptığı giysi tasarımları olarak koleksiyonlarının \%16-20'si organik kumaşların yer aldığı tasarımlardan oluşmaktadır. Üreticilerin büyük çoğunluğu organik kumaştan yapacağ1 koleksiyon için pazar araştırması yapmaktadır. Yine işletmelerin yarıdan fazlası tüketicilerin organik giysi talebini karşılayabiliyor durumdadır. İşletmeleri yarısı organik tekstil üretiminde 
kullanılan yardımcı malzemelerinde de organik olmasını dikkate almaktadır ve yine büyük çoğunluğu organik giysilerde bilgilendirme etiketi bulundurmaktadır.

İşletmelerin yarıya yakını üretim şekli olarak fason üretimi yapmaktadırlar. Yine işletmelerin tasarımlarında kullandıkları organik kumaşları iç piyasadan temin etmektedir. İşletmelerin giysi tasarımlarının tamamı organik kumaşlardan yapılan ürünlerden oluşmaktadır. İşletmeler organik tekstil ürünlerinin üretilmesinin işletmelerine sağladığı en büyük katkının işletmenin imajını güçlendirme olduğunu belirtmiş̧tir. Giysi tasarımında organik kumaşların kullanım durumuyla ilgili olarak, bu ürünler benimsenmeli ve ülke stratejisi şeklinde oluşturulması gerektiğini belirtmiştir. Organik giysi tasarımında yaşanılan en önemli sorun olarak, maliyetlerin yüksek olmasını belirtmiştir.

Sanjuán ve Ark. 2003 yılında yaptıkları bir araştırmada işletmelerin hedefledikleri yeni pazarlara yönelik olarak organik maddeli ürünlerin dağıtımı konusunu güçlendiriyor olması; doğal ve sağlıklı ürün kullanımının yanında, çevre korunmasını gerektirecek organik tüketim ürünlerini de teşvik etmektedirler. Bu gün tekstil malzemelerinde organik olanlara yapılan talepler her gün artmaktadır. Organik üründe tüm şartlara sahip olan Türkiye sanayisi ve tarım arazisiyle ender ülkelerdendir. Türkiye'nin gelişmiş̧ olan ülkelere yakın olması önemli bir avantajdır. Türkiye, AB ye oranla organik ürünleri kullanmakta düşük miktardadır. Bunun nedenini de bilgi eksikliğinin yanında fiyat olarak da yüksek oluşudur. Firmaların bu konuda alacakları sorumluluklar halkın bilgilendirilmesi ve diğer konular açısından önemlidir. Kitlesel reklam ve tanıtım neticesinde tüketiminin de arttırılması sağlanabilmektedir. Bunun sonucunda ülkeye önemli firsat sağlaması Türkiye'ye dünya liderliğini de getirebilmektedir. $\mathrm{Bu}$ da ülke ekonomisi ve sanayisi açısından önemli unsurlardandır.

\section{Kaynaklar}

Akgüngör, S., Miran, B., Akbay, C. 2010. Consumer willingnessto pay fororganicproducts in urban Turkey. Journal of International FoodandAgribusiness Marketing, 299-313.

Aldanondo-Ochoa, A. M. ve Almansa-Saez, C., (2008), The Private Provision of Public Environment: Consumer Preferences for Organic Production Systems, Land Use Policy, 26, 669-682.

Aldanondo-Ochoa, A. M. ve Almansa-Saez, C., (2008), The Private Provision of Public Environment: Consumer Preferences for Organic Production Systems, Land Use Policy, 26, 669-682. 
Ayla, D. \& Altıntaş, D. (2017). Organik Üretim Ve Pazarlama Sorunları. Kastamonu Üniversitesi İktisadi ve İdari Bilimler Fakültesi Dergisi, 19 (4) , 7-17

Bayraktar, T., (2005), Tekstil ve Konfeksiyon Sektöründe Ekoloji ve Ekolojik Etiketler, İTKİB Genel Sekreterliği, İstanbul.

Çakır, M. (2019). Organik Üretimde Pazarlama Uygulamaları ve Tüketici Tercihleri Üzerine Bir Değerlendirme, C.Ü. İktisadi ve İdari Bilimler Dergisi, 20(1), 309-319.

Çalışkan, S., M. E. Çalışkan, S. Karanlık, S. ve M. Arslan. 2009. Geleneksel ve Organik Üretim Sistemlerinin Pamuk Bitkisinin Büyüme ve Verimi Üzerine Etkileri. 1. GAP Organik Tarım Kongresi, 1720 Kasım, Şanlıurfa

Çelik, A. \& Başal, M. (2021). Farklı Kültürlere Ait Yöneticiler ile Türk Yöneticiler Arasındaki Çatışma Nedenleri ve Müzakere Tarzlarının Karşılaştırılması: İstanbul'daki Tekstil Firmalarında Çalışan Üst ve Orta Kademedeki Yöneticiler, IJSS, 2021, Volume 5, Issue 22, p. 1-32.

Demiryürek, K. ve M. Aydoğan, 2010.Türkiye’nin Organik Tarım ve Gıda Ürünleri İhracatının Sosyal A ̆g Analizi İle Ortaya Konulması. Türkiye IX. Tarım Ekonomisi Kongresi, Cilt I, 333-340, Şanlıurfa.

Er, Celal (2009), Organik Tarım Bakımından Türkiye'nin Potansiyeli, Bugünkü Durumu ve Geleceği, İstanbul Ticaret Odası Yayınları, İstanbul

Ersun N. ve Kahraman A., (2011), Türkiye'de Organik Tarım ve İyi Tarım Uygulamaları, İstanbul Ticaret Odası Yayınları, Yayın No: 2010-101, İstanbul

Gam, H. J., Cao, H., Farr, C. ve Kang, M., (2010), Quest for the Eco-appreal Market: A Study of Mothers' Willingness to Purchase Organic Cotton Clothing for Their Children, International Journal of Consumer Studies, 34, 648-656.

Hassan, D, Monier-Dilhan, S, Nichèle, V, Simioni, M. 2009. OrganicFoodConsumptionPatterns in France. PreConference Workshop, DietandObesity: Role of PricesandPoliciesAugust 16. https://www.dunya.com/turkiyede-organik-tekstil-sektoru-ve-organik-tekstillerin-sundugu-firsatlar,-oga$\underline{85329 \mathrm{~h} . \mathrm{htm}}$

İnci, Hakan; Karakaya, Ersin ve Şengül, A. Yusuf (2017), “Organik Ürün Tüketimini Etkileyen Faktörler (Diyarbakır İli Örneği)”, KSÜ Doğa Bilimleri Dergisi, 20(2), 137-147. 
Khare, A. ve Varshneya, G., (2017), Antecedents to Organic Cotton Clothing Purchase Behaviour: Study on Indian Youth, Journal of Fashion Marketing and Management: An International Journal, 21(1), 51-69.

Kotler, P., Kartajaya, H. ve Setiawan, I., (2017), Pazarlama 4.0, Çev. Nadir Özata, Optimist Yayınevi, İstanbul

Kuyumcu, O., Türkiye'de Organik Tekstil Sektörü ve Organik Tekstillerin Sunduğu Frrsatlar, Organik Tekstil Nedir, https://www. dunya.com/ gundem/turkiye039de-organik-tekstil-sektoru-ve-organiktekstillerinsundugu-haberi-112121, Erişim Tarihi: 09.04.2018.

Odabaşı, Y. ve Barış, G., (2002), Tüketici Davranışı, 6. Baskı, MediaCat Kitapları, İstanbul. 6. Bocock, R., (2005), Tüketim, Çev. İrem Kutluk, 2. Baskı, Dost Yayınları, Ankara

Tarakçığlu, I., (2008), Organik Pamuk ve Tekstil Sanayi, İstanbul Ticaret Odası Yayını, İstanbul.

Willer, H. and L. Klicher, (eds.), 2011. The World of OrganicAgriculture. StatisticsandEmergingTrends 2011. FiBL-IFOAM Report. IFOAM, Bonn andFiBL, Frick

Zaltman, G. ve Zaltman, L. (2017), Pazarlama Metaforları, Çev. Ümit Şensoy, MediaCat Kitapları, İstanbul. 